\title{
Circuit
}

Musiques contemporaines

\section{Making Music with My Friends: Collaborations with the ECM+}

\section{Gordon Fitzell}

Volume 28, numéro 2, 2018

URI : https://id.erudit.org/iderudit/1051299ar

DOI : https://doi.org/10.7202/1051299ar

Aller au sommaire du numéro

Éditeur(s)

Circuit, musiques contemporaines

ISSN

1183-1693 (imprimé)

1488-9692 (numérique)

Découvrir la revue

Citer ce document

Fitzell, G. (2018). Making Music with My Friends: Collaborations with the ECM+ Circuit, 28(2), 110-111. https://doi.org/10.7202/1051299ar d'utilisation que vous pouvez consulter en ligne.

https://apropos.erudit.org/fr/usagers/politique-dutilisation/ 


\title{
Making Music with My Friends: Collaborations with the ECM+
}

\author{
Gordon Fitzell
}

In recognition of the $30^{\text {th }}$ anniversary of the Ensemble contemporain de Montréal (ECM+), I am pleased to have the opportunity to reflect upon our past collaborations. To work with such talented and visionary musicians is an honour, and I am indebted to the group for the many wonderful opportunities they have afforded me over the past two decades. It is no surprise to me that the $\mathrm{ECM}+$ has remained a vital part of the contemporary music scene for thirty years.

My first encounter with the ensemble came in 2000 when I was one of four composers selected for their comprehensive 18-month emerging composers project, Generation, which included the group's first coastto-coast tour of Canada. I was thrilled to have been chosen for this program, as I had come quite late to composition and was still somewhat of an unknown quantity. From the outset, I was immediately struck by the inspiring artistry and energy of conductor Véronique Lacroix, and indeed of the entire ensemble. a work commissioned once again by the ECM+. Featuring guests Tim Brady on electric guitar and Lori Freedman on bass clarinet, the ensemble was one of six to perform the work simultaneously across the country.

Immediately on the heels of this project came a third commission, this time involving Lacroix's Ensemble de flûtes Alizé, in conjunction with the ECM+. This project resulted in Magister Ludi (2010/14), a solo cello and flute octet work featuring, among others, Mariève Bock on cello and Marie-Hélène Breault on piccolo. In addition to the Montreal premiere, Lacroix mounted the work the following season as guest conductor of Mark Takeshi McGregor's Tempest Flute Ensemble in Vancouver. The musicians were incredibly impressed by Lacroix's extensive knowledge of each work on the program. (I still remember one player exclaiming in amazement, "Oh my God, she knows every note!").

Our most recent collaboration came in 2013/2014, when the ECM+ recorded an album of my music. The collection included the three commissioned works (Flux, Pangaea Ultima and Magister Ludi) plus two others (violence (2001) and evanescence (2001/2006)). It was a joy working with such capable, well-prepared musicians. In addition to scheduling substantial rehearsal time, the ECM+ programmed a concert that included two of the album pieces-evanescence, a 
sextet with live electronics, and Flux, a large chamber work featuring Vancouver clarinetist François Houle.

Some months after the release of the recording, the title track Magister Ludi received a nomination for Classical Composition of the Year at the 2015 JunO Awards. We were especially pleased because the recording of that particular work was rather memorable. We had recorded several complete takes and second passes of key sections, and decided to make one last attempt at capturing the entire piece. I remember discussing, prior to the final take, our intention to execute a pure artistic expression of the work as a whole. We recalled Hermann Hesse's notion of a seemingly eternally present universe, referencing the work's eponymous title. We hit the red button, and the group-now collectively focused-brilliantly channeled the essence of the work. The closing notes of the performance extended into a long pause, and we all looked at one another in silent appreciation of the moment. To this day, that is one of my most cherished musical memories.

In closing, I wish to thank all the musicians of the $\mathrm{ECM}+$ for sharing their vast abilities, imagination and enthusiasm with me. I am grateful not only for our musical collaborations, but also for the cultural window that our relationship has afforded me. The early faith that the ECM+ placed in me not only led to further musical journeys, but also provided me with a much deeper appreciation of Quebec culture. To this day, I regularly visit the Musée d'art contemporain de Montréal to view its exquisite collection of paintings by Automatistes Paul-Émile Borduas and Jean-Paul Riopelle. In fact, I have prints of works by both painters in my home, and a copy of Refus Global handy at all times!

To Véronique and the many devoted members of the ECM+ organization, past and present, I offer my sincerest congratulations. Bravo! 